Агапов П. В.

\author{
ОТЗЫВ \\ НА ДИССЕРТАЦИЮ САЛЬНИКОВА АРТЕМА ВЛАДИМИРОВИЧА \\ «УГОЛОВНО-ПРАВОВОЕ РЕГУЛИРОВАНИЕ ОТВЕТСТВЕННОСТИ \\ ЗА БАНДИТИЗМ: ИСТОРИЯ, СОВРЕМЕННОСТЬ И ПЕРСПЕКТИВЫ», \\ ПРЕДСТАВЛЕННУЮ НА СОИСКАНИЕ УЧЕНОЙ СТЕПЕНИ \\ КАНДИДАТА ЮРИДИЧЕСКИХ НАУК ПО СПЕЦИАЛЬНОСТИ \\ 12.00.08 «УГОЛОВНОЕ ПРАВО И КРИМИНОЛОГИЯ; \\ УГОЛОВНО-ИСПОЛНИТЕЛЬНОЕ ПРАВО»
}

Научное познание бандитизма как уголовно наказуемого деяния и криминологического явления не теряет своей актуальности вот уже не одно десятилетие. При этом в многочисленных научных работах затрагивается целый комплекс проблем, связанных с уголовноправовой характеристикой данного группового посягательства, анализируются сложные вопросы его квалификации, отграничения и возможной совокупности со смежными составами преступлений, отмечаются новые тенденции его характеристики как криминального явления. Как известно, банда представляет собой наиболее опасную форму соучастия в преступлении, что актуализирует ее анализ через призму этого наиболее сложного института уголовного права. Еще одно немаловажное обстоятельство, свидетельствующее о необходимости продолжения уголовно-правовых исследований бандитизма, - процессуальные сложности его доказывания, что подтверждает высокий процент оправдательных приговоров по соответствующей категории уголовных дел. По справедливому утверждению автора диссертации, трудности, возникающие при привлечении к уголовной ответственности организаторов и участников банд, вызваны, в том числе, и дефектами юридической техники, а также противоречивостью судебно-следственной практики, дискуссионным характером ряда положений постановления Пленума Верховного Суда РФ от 17.01.1997 № 1 «О практике применения судами законодательства об ответственности за бандитизм» (с. 6-7).

Сказанное в достаточной мере подтверждает актуальность избранной темы диссертационного исследования.

Научная новизна диссертации определена небезуспешной попыткой соискателя ученой степени осуществить комплексное теоретико-прикладное исследование состава бандитизма с учетом современных законодательных и правоприменительных тенденций, изменения социально-правовой сущности данного противоправного деяния, а также предложить ряд изменений в конструкцию соответствующей нормы уголовного закона.

Оценка результатов исследования А. В. Сальникова в сравнении с данными, полученными ранее при проведении исследований по аналогичной тематике, показала, что автором сформулированы оригинальные положения, до настоящего времени не отраженные в научной литературе. Новизной, в частности, обладают:

- адаптация к потребностям уголовно-правового регулирования (ст. 35, 209 УК РФ) положений Конвенции Организации Объединенных Наций против транснациональной организованной преступности о количественном признаке организованной преступной группы, что позволит упростить разграничение организованной группы с группой лиц по предварительному сговору (с. 56);

- тезис о существующих проблемах отграничения бандитизма от смежных составов организации незаконного вооруженного формирования или участия в нем (ст. 208 УК РФ), организации террористического сообщества и участия в нем (ст. 205.4 УК РФ) с учетом наличия ряда сходных признаков и отсутствия четких критериев разграничения указанных составов и путях их решения (с. 142); 
- положение о необходимости снижения предусмотренных санкциями статьи 209 УК РФ сроков лишения свободы с учетом изменения социальной оценки бандитизма и современной практики назначения наказания (с. 10-11, 146-147);

- обоснование соискателем возможности закрепления в статье 209 УК РФ поощрительного примечания, предусматривающего освобождение от уголовной ответственности для участников вооруженных организованных преступных групп, созданных с целью совершения нападений на граждан и организации, в случае их активного способствования раскрытию преступлений (с. 151);

- предложенная дефиниция вооруженности банды, включающая наличие у ее членов, помимо огнестрельного, холодного (в том числе метательного) оружия, различных взрывных устройств, газового и пневматического оружия, также электрошоковых устройств и искровых разрядников (с. 154).

Автора обоснованно тревожит непоследовательность законодателя в вопросе о снижении возраста уголовной ответственности за ряд преступлений против общественной безопасности. Получается парадоксальная ситуация: ответственность за участие в террористическом сообществе (ч. 2 ст. 205.4 УК РФ) и за участие в незаконном вооруженном формировании (ч. 2 ст. 208 УК РФ) наступает с 14 лет, тогда как для участников банды (ч. 2 ст. 209 УК РФ) она осталась прежней (с 16-летнего возраста). Однако если подросток способен осознавать опасность и все цели (политические, религиозные, идеологические) осуществления террористической деятельности, то, очевидно, он может осознавать и общественную опасность участия в банде (с. 97).

Убедительной представляется и позиция соискателя ученой степени об отсутствии необходимости исключить из УК РФ норму об ответственности за бандитизм (с. 126-127). В качестве главного аргумента он приводит законодательную тенденцию конструирования новых составов, предусматривающих ответственность за создание преступных формирований и участие в них. Кроме того, данная уголовно-правовая норма (ст. 209 УК РФ) продолжает доказывать свою эффективность уже на протяжении достаточно долгого периода времени. И это еще один немаловажный аргумент, учитывая стабильно высокий уровень корыстнонасильственной и организованной преступности в нашей стране.

Вместе с тем возникшая криминализационная избыточность привела к ситуации, когда четко отграничить бандитизм от смежных составов становится чрезвычайно сложно. Как правильно подчеркивает автор диссертации, в составах преступлений, предусмотренных ст. 209, 208 и 205.4 УК РФ, существует ряд сходных признаков, что способствовало проблеме их разграничения в условиях конкуренции норм. Это аргумент в пользу дальнейшего совершенствования законодательства об ответственности за создание и участие в организованных преступных формированиях. И важным шагом на этом пути стало бы закрепление в составе бандитизма в качестве цели совершение корыстно-насильственных преступлений (с. 141). Данный авторский тезис также заслуживает безусловной поддержки.

Степень обоснованности научных положений, выводов и рекомендаций, сформулированных в диссертачии, их достоверность определены качеством и объемом источников первичной научной информации, использованием апробированного научно-методического аппарата, внутренней непротиворечивостью представленных в диссертации суждений, соответствием теоретических выводов автора с эмпирическими данными документального и социологического анализа. Большинство рассуждений соискателя основаны на общепринятых и корректно используемых выводах фундаментальных и прикладных наук, подтверждены согласованностью новых результатов с результатами, полученными в процессе исследований других авторов.

Работа представляет собой логически последовательное, завершенное и композиционно целостное научное исследование, которое сочетает в себе:

- формально-логический анализ нормативных правовых актов, в том числе с учетом генезиса нормы, устанавливающей ответственность за бандитизм, в российском законодательстве и зарубежного опыта конструирования уголовно-правовых запретов создания организованных преступных групп и участия в них; 
- изучение значительного объема отечественных и зарубежных научных источников по теме диссертации;

- социологический анализ общественного и профессионального мнения о проблемах уголовного законодательства и практики его применения;

- документальный анализ судебной практики по уголовным делам Верховного Суда Российской Федерации и ряда региональных судов;

- статистический анализ данных о современном состоянии бандитизма и применении мер уголовно-правового характера в отношении осужденных за совершение данного преступления.

Следует отметить, что сбор, анализ и интерпретация результатов обеспечены репрезентативной эмпирической базой, соблюдением методологических принципов и методических требований к проведению научных исследований.

Значимость полученных автором диссертачии результатов для развития юридической науки определяется тем, что им проведено новое теоретико-прикладное исследование состава бандитизма с учетом существенно изменившегося в правоприменительной практике и уголовно-правовой доктрине понимания его социально-правовой сущности. Содержащиеся в рецензируемой работе положения и выводы могут быть использованы при проведении дальнейших уголовно-правовых и криминологических исследований бандитизма, в практической деятельности правоохранительных органов, при совершенствовании норм УК РФ, а также при разработке Пленумом Верховного Суда Российской Федерации новых разъяснений по вопросам применения законодательства об ответственности за бандитизм.

Вместе с тем результаты апробации материалов диссертации считаем не вполне достаточными. Ее основные положения докладывались и обсуждались на международных и всероссийских конференциях, отражены в семи научных статьях, три из которых опубликованы в журналах, входящих в перечень рецензируемых научных изданий, рекомендованных Высшей аттестационной комиссией при Министерстве образования и науки Российской Федерации. Однако, к сожалению, отсутствуют сведения о внедрении результатов исследования в практическую деятельность.

В целом положительно оценивая научную работу А. В. Сальникова, следует отметить, что ряд его суждений вызывает критические замечания, которые могут инициировать дискуссию в процессе публичной защиты, а некоторые положения представляются не вполне убедительными.

1. Так, автор зачастую критикует положения постановления Пленума Верховного Суда РФ от 17.01.1997 № 1 «О практике применения судами законодательства об ответственности за бандитизм», отмечая их противоречивость и дискуссионность. Подобные рассуждения приводят его к мысли о необходимости внесения изменений в этот документ.

Значение актов судебного толкования сложно переоценить, поскольку они дают ориентиры нижестоящим судам и другим практическим органам в вопросах правоприменения. Как известно, рекомендации, исходящие от высшей судебной инстанции, должны быть предельно четкими, исключающими их двусмысленное толкование и не требующими дополнительной конкретизации. Полагаем, что таким требованиям не отвечают предлагаемые изменения в п. 2 названного постановления Пленума Верховного Суда РФ: «Бандой может быть признана организованная преступная группа, совершившая лишь одно нападение, если будет установлено, что данное преступление является одним из эпизодов, этапов преступной деятельности этой группы и данным преступлением ее преступная деятельность не ограничивалась или не должна была ограничиться» (с. 62). Сразу возникают вопросы: 1) каким образом следственные органы (суд) должны устанавливать, что первое нападение - это лишь эпизод (этап) планируемой преступной деятельности членов задержанной группы? 2) как установить, что совершенным преступлением деятельность такой группы не ограничивалась (не должна была ограничиться)? Полагаем, что нередко даже сами участники криминального объединения не могут достоверно знать (предполагать) о том, что совершение ими первого преступления - это лишь начальный этап будущей преступной деятельности. Кроме того, не 
следует забывать, что планирование и подготовка такой группой преступлений (с учетом конспирации и других обстоятельств) носит в основном интеллектуальный характер и, как правило, не оставляет материальных следов. В связи с этим представляется, что предлагаемые изменения в постановление Пленума Верховного Суда РФ от 17.01.1997 № 1 скорее усложнят, чем упростят уголовно-правовую борьбу с бандитизмом.

2. Рассматривая бандитизм как объект исследования, А. В. Сальников констатирует, что таковым выступает общественная безопасность как совокупность общественных отношений, устанавливаемых и охраняемых государством, нормальных и безопасных условий жизнедеятельности общества в целом и отдельных его граждан (с. 79). Однако из содержания диссертации остается непонятным, каков механизм причинения вреда этим отношениям. А ведь, как верно отмечал Владимир Кузьмич Глистин, решение именно этого круга вопросов позволяет понять ту сферу, где происходят изменения, а следовательно, и отыскать наиболее эффективные средства защиты. Хотелось, чтобы в процессе публичной защиты соискатель ученой степени обозначил структурные элементы общественной безопасности (предмет, субъекты и их социальную связь).

3. Существенным недостатком диссертации следует признать слабую аргументацию ряда положений, в том числе и выносимых на защиту. Например, в положении № 5 диссертант убеждает в необходимости исключить из ст. 209 УК РФ часть третью. Однако в качестве основного аргумента такого решения он приводит данные судебной статистики, позволяющие сделать вывод о том, что за последние шесть лет вынесено всего шесть судебных решений в отношении осужденных по ч. 3 ст. 209 УК РФ, а наказание за них назначается ниже низшего предела (с. 11). Еще более сомнительной представляется аргументация о сложностях при вменении данного квалифицирующего признака. Как представляется, основная задача исследователя и заключается в том, чтобы предложить практические рекомендации по устранению выявленных проблем. В свою очередь, предложения об исключении отдельных норм из УК РФ должны быть более основательно криминологически обоснованы.

Говоря о «большом количестве споров по поводу признака вооруженности банды и незаконного вооруженного формирования», автор критикует существующие доктринальные позиции по этому вопросу, но о своем решении этой проблемы предпочитает умалчивать, ограничиваясь лишь сформулированным тезисом о том, что «основная задача незаконного вооруженного формирования - способность вести боестолкновения» (с. 135-137).

Правомерно рассуждая о необходимости увеличения количественного показателя организованной группы (до трех или более лиц) в соответствии с положениями Конвенции Организации Объединенных Наций против транснациональной организованной преступности (с. 56), соискатель тем не менее не предлагает конкретных решений законодательного регулирования данного вопроса. Вместе с тем в этой части работы желательно было бы сформулировать авторскую редакцию ч. 3 ст. 35 УК РФ.

Вышеуказанные замечания, как видно из их содержания, во многом дискуссионны и не влияют на общую положительную оценку диссертации.

На основании изучения текста диссертации, автореферата и научных трудов соискателя можно заключить:

1. Работа А. В. Сальникова «Уголовно-правовое регулирование ответственности за бандитизм: история, современность и перспективы» представляет собой самостоятельно выполненное, логически цельное, аргументированное исследование важной уголовно-правовой проблемы, результаты которого имеют значение для развития отечественной юридической науки и практики противодействия преступности.

2. Диссертация представляет собой научно-квалификационную работу, которая соответствует критериям, установленным ч. 2 п. 9 Положения о присуждении ученых степеней, утвержденного Постановлением Правительства Российской Федерации от 24 сентября 2013 г. № 842.

3. Автор диссертации - Артем Владимирович Сальников - заслуживает присуждения искомой ученой степени кандидата юридических наук по специальности 12.00 .08 «Уголовное право и криминология; уголовно-исполнительное право». 


\section{Официальный оппонент:}

Агапов Павел Валерьевич, ведущий научный сотрудник отдела научного обеспечения прокурорского надзора и укрепления законности в сфере федеральной безопасности, межнациональных отношений и противодействия экстремизму НИИ Университета прокуратуры Российской Федерации, доктор юридических наук, доцент

123022, г. Москва, 2-я Звенигородская ул., д. 15, каб. 206; тел. 8-499-256-61-21; адрес электронной почты: niigp@msk.rsnet.ru 